\title{
Effect of Liquidity on Financial Performance of Firms Listed at the Nairobi Securities Exchange, Kenya
}

\author{
Grace Akenga \\ Department of Business Administration, Chuka University
}

\begin{abstract}
Liquidity refers to the ability of a firm to meet its obligations as and when they fall due. In order to meet their obligations, firms are expected to hold a certain percentage of their total finance in cash. However, majority of the institutions especially financial institutions tend to focus only on profit maximization at the expense of liquidity management. It is therefore the role of financial managers to establish effective mechanisms of meeting a firm's obligations and profit maximization. The objective of the study was to establish the effect of current ratio, cash reserves and debt ratio on financial performance of firms listed at the Nairobi Securities Exchange (NSE). Causal research design was adopted. Purposive sampling technique was used to select 30 firms. The data was analyzed using descriptive and inferential statistics It was found that current ratio and cash reserves have a significant effect on ROA with a $p$ value of less than 0.05.The debt ratio was found to have no significant effect on ROA as it had a significance level of 0.571.
\end{abstract}

Keywords: Liquidity, financial performance, current ratio, cash reserves, debt ratio

\section{Introduction}

Liquidity refers to theability of a firm to meet short term financial obligations by converting the short term assets into cash without incurring any loss .According to [3], assets are considered to be high-quality liquid assets if they can be easily and immediately converted into cash at little or no loss of value. Markets are considered to be liquid when those who have assets holdings can sell them at prices that do not involve considerable losses so as to gain the finances they need to fulfill other commitments

Financial performance refers to the process of measuring the results of a firm's policies and operations in monetary terms. It is used as a measure of a firm's overall financial health over given period of time. Institutions have various measures of financial performance. However, the common measures of financial performance are the Return on Assets and Return on Equity.

Companies try to achieve the twin conflicting objectives of liquidity and improved financial performance by selecting a diversified and balanced asset portfolio within the framework of the regulators .Profitability is improved for banks that hold liquid assets, however, there is a point at which further holding of liquid assets diminishes an institution's profitability or it remains constant. The firms are also expected to hold onto a certain percentage of their liquid assets. For instance Kenyan banks are required to maintain a statutory minimum of twenty percent $(20 \%)$ of all its deposit liabilities, matured and short term liabilities in liquid assets. This may result into an opportunity cost of holding onto the assets rather than venturing into investment. Financial managers must therefore strive to achieve a balance between liquidity and profitability.

The most suitable measures of liquidity are the current ratio, debt ratio and amount of cash reserves. Current ratio measures the firm's ability to meet its current obligations as and when they fall due. A ratio of 2:1 is said to be efficient as it implies that the firm is capable of meeting its obligations as it falls due, hence an indication of better financial performance. The debt ratio represents the proportion of the company's assets financed by debt. The higher the debt ratio the higher the amount of debt employed by the company to finance its assets, hence high financial risk. For such a company, chances of yielding low profits are very optimal. The amount of cash reserves refers to the money a firm or an individual holds in hand so as to meet short term and emergency funding needs. The higher the amount of cash reserves the higher the capability of the firm to meet its unplanned emergencies.

The Nairobi Securities Exchange (NSE) was constituted in 1954 as a voluntary association of stock brokers registered under the Societies Act. The Capital Markets Authority of Kenya through the Capital Markets Act was developed to oversee the development of Kenya capital markets and regulate the NSE. It provides trading platform for listed securities and overseeing its member firms. Shares traded in the NSE are from different sectors, financial sector companies include; banking, investment and insurance. Others include manufacturing and allied, telecommunications and technology, agricultural, automobiles and technology, commercial and services, construction and allied growth and lastly energy and petroleum. The NSE has a total of 66 listed institutions. The NSE 20 share index closed the year 2016 at 4,598 points gaining 24 percent from its opening level in July 2012.The CMA board has developed a framework for the management of the authority's short, medium and long term liquidity requirements thereby ensuring that all financial liabilities are settled as they fall due.

\section{Literature Survey}

This section reviews literature relating to liquidity and financial performance and also discusses the various variables used to measure both liquidity and financial performance. 


\section{International Journal of Science and Research (IJSR) \\ ISSN (Online): 2319-7064 \\ Index Copernicus Value (2015): 78.96 | Impact Factor (2015): 6.391}

\section{Liquidity}

Liquidity refers to the ability of affirm to meet both its long and short term obligations as andwhen they fall due. The obligations of a firm may include; meeting daily operating costs, unforeseen emergencies, contingencies or accidents. In order to meet such obligations effectively, firms must therefore hold a certain percentage of their total liquid assets in form of cash. A firm that is capable of meeting its obligations as and when they fall due creates a good image with its customers more so the creditors. To ensure that a firm remains liquid, financial managers must construct an appropriate asset-liability mix in that the total liabilities must not exceed the total assets of a firm .Liquidity ratios have been over the years preferred to be effective measures of liquidity. The ratios include the current ratio, quick ratio and debt ratio. Aside from the liquidity ratios, amount of cash reserves held by a firm can also be used to determine how capable a firm is at meeting its obligations.

\section{Current Ratio}

It is a liquidity ratio that measures the firm's ability to meet its long and short term obligations. To gauge this ability, the current ratio considers the current total assets of a firm (both liquid and illiquid) relative to its current total liabilities. It is called current because unlike some liquidity ratios, it incorporates all current assets and liabilities. The current ratio is mainly used to give an idea of a firm's ability to pay back its liabilities (debts and account payable) with its assets (cash, marketable securities, inventory, accounts receivable). As such, current ratio can be used to make a rough measurement of a firm's financial health. The higher the current ratio, the more capable a firm is of meeting its obligations as and when they fall due, as it has a larger proportion of assets value relative to its liabilities' value. A ratio under 1 indicates that a firm's liabilities are greater than its current assets and suggests that a firm would be unable to pay off its obligations if they came due. While a current ratio below 1 indicates that a firm is not in good financial health, it does not necessarily mean that it will go bankrupt. On the other hand, a high ratio (over 3 ) does not necessarily mean that a company is in a state of financial well-being. Depending on how a firm's assets are allocated, a high current ratio may suggest that a firm is not using its current assets efficiently or is not managing its current assets well. The current ratio gives a sense of efficiency of a firm's operating cycle or its ability to turn its product into cash. Firms that have trouble getting paid on their receivable or have long inventory turnover run into liquidity problems because they are unable to alleviate their obligations.

\section{Quick Ratio}

It's a ratio that measures a firm's ability to meet its short term obligations using its most liquid assets. For this reason, the ratio excludes inventory from current assets. In Kenyan context, the quick ratio measures the shilling amount of liquid assets available for each shilling of current liabilities. Thus, a quick ratio of 1.5 means that a company has Ksh 1.5 of liquid assets available to cover each Ksh.1 of current liabilities. According to [14], the higher the quick ratio the better the firm's liquidity position. The ratio derives its name presumably from the fact that asset such as cash and marketable securities are quick sources of cash .It is vital that a firm has enough cash on hand to meet its accounts payable, interest expense and other bills when they fall due. A common rule of thumb is that firms with a quick ratio greater than 1 are sufficiently able to meet their short term liabilities. Generally, low or decreasing quick ratios suggest that a company is over-leveraged, struggling to maintain or grow sales, paying bills too quickly or collecting receivables too slowly. On the other hand, a high or increasing ratio generally indicates that a company is experiencing high growth rate, quickly converting receivables into cash, and easily able to cover its financial obligations.

\section{Debt Ratio}

It is the ratio of an institution's total debts to its total assets. It is interpreted as the proportion of the company's total assets financed by debt. The higher the ratio the more leveraged a firm is, implying greater financial risk[14]. Debt ratios vary intensely among industries, with capital intensive businesses such as utilities and pipelines having much higher debt ratios compared to others. A debt ratio of $30 \%$ may be too high for an industry with volatile cash flows, in which most businesses take on low debts. A firm with high debt ratio finds it expensive to borrow and could find itself in a crunch if circumstances change. Conversely, a debt ratio of $40 \%$ may be easily manageable for a firm in a sector such as utilities where cash flows are stable and higher debt ratios are the norm. A debt ratio of greater than $100 \%$ implies that a company has more debt than assets. On the other hand, a debt ratio of less than $100 \%$ indicates that a firm has more assets than debt. Used in conjunction with other measures of financial health, the debt ratio can help investors determine a company's risk level.

\section{Cash Reserves}

It is the amount a firm holds in hand so as to meet its short term as well as emergency needs. It can also be referred to as a type of short term, highly liquid investments that earn a low rate of return. Having a significant reserve gives a firm the ability to make huge purchases immediately, as it enables a firm to have the necessary liquidity needed to meet both expected and unexpected expenses in the short run and also have cash in hand for potential investments [6]. Short term assets such as a 3 month treasury bill are considered to be cash reserves because of their high frequency of exchange and early maturity. Banks which are considered to be the most vital in an economy, are subject to the requirements on the amount of cash reserves they must hold, as mandated by the Central Bank of Kenya. The reserves are held either inform of vault cash or deposits in the Central Bank. Firms having insufficient cash reserves resort to credit or in extreme cases may be forced into bankruptcy.

\section{Financial Performance}

Financial performance refers to a subjective measure of how well a firm can use assets from its primary mode of business and generate revenue .It can also be used as a general measure of a firm's overall financial health over a given period of time. It can be measured using Return on Assets.

\section{Return on Assets}

It is an indicator of how profitable a business is relative to its total assets. It gives an idea of how efficient the management is using its assets to generate earnings. The assets of the company are comprised of both debt and equity. Both of

\section{Volume 6 Issue 7, July 2017 www.ijsr.net}




\section{International Journal of Science and Research (IJSR) \\ ISSN (Online): 2319-7064}

Index Copernicus Value (2015): 78.96 | Impact Factor (2015): 6.391

these types of financing are used to fund the operations of the company [1]. The ROA figure gives investors an idea of how effectively the company is converting the money it has to invest into net income. The higher the ROA number the better, because the company is earning more money on less investment. For example, if one company has a net income of Kshs.5 million, its ROA is $20 \%$; however, if another company earns the same amount but has total assets of Kshs.10 million, it has a ROA of $10 \%$. Based on this example, the first company is better at converting its investment into profit.

\section{Theoretical Framework}

This chapter discusses theories and models used to offer a supportive argument about liquidity and financial performance. The theories that offer a deeper understanding on the importance of liquidity is; Keynesian Liquidity Preference Theory and the Miller-Orr Cash Management Model. Profitability has been supported by the Sharpe's Single Index Model and the Capital Asset Pricing Model.

\section{Keynesian Liquidity Preference Theory}

Keynes (1936) in his study "The general Theory of employment, interest and money" identified three main motives of holding cash. The motives are; speculative, precaution and transaction motives. The speculative motive is the need to hold cash in order to take advantage of changes in bargained purchase and suitable interest rates fluctuation .Most firms have opted to the option of holding onto their marketable securities so as to meet these motives. The precautionary motive is when the institution wants to hold cash so as to meet some unforeseen emergencies, contingencies and accidents. Money needed by institutions in order to meet their economic day to day activities is known as the demand for money for transaction motive. Individual firms are therefore expected to hold on to cash hence incurring an opportunity cost of having to let go the earnings they would have gained if they ventured the cash into profitable investments. A good example is the case of Kenyan banks where they are required to maintain a statutory minimum of twenty percent of all its deposits liabilities, matured and short term liabilities in liquid assets.

\section{Miller-Orr Model}

The model was formulated in 1996 by Merton Miller and Daniel Orr. Miller-Orr model is a probabilistic model that makes realistic assumptions regarding the uncertainty in cash flows. The model assumes that the distribution of a firm's daily net cash flows is approximately normal. Each day the net cash flow could be the expected value of some higher or lower value drawn from a normal distribution. Therefore the daily net cash flow follows a trendless random walk.

\section{Sharpe's Single Index Model}

The model was developed by William Sharpe in 1964.It is a single index model because it relies on a single index that represents the security market. Return of each security is only compared to the market return (market index).Sharpe suggested that the relationship of each security with the market index gives reasonably accurate information about the security and that it is needless to study the relationship of each security with every other security. To obtain the market model, we regress the returns on the security against returns on the market. The NSE 20 share index provides a list of all the securities traded and their performance. An investor is therefore able to select an optimal portfolio based on the portfolios' returns.

\section{Empirical Framework}

Various studies have been carried out to determine the relationship between liquidity and financial performance in different sectors of the economy, locally and also internationally. Some of the empirical studies are summarized below.

[1] Conducted a research to find out the degree to which effective liquidity management affects profitability in Jordanian commercial banks and how and commercial banks can enhance their liquidity management and profitability positions. Based on the research findings, [1] concluded that, liquidity management has effect on profitability as measured by ROE and ROA, where the effect of the investment ratio and quick ratios on the profitability is positive when measured by ROE, and the effect of capital ratio on profitability is positive as measured ROA.

A study by [4] concluded that a firm's profitability and liquidity are affected by working capital management. The study used pooled data for the period 2006 to 2008 to assess the companies listed in the Vietnam Stock Exchange. The study focused on the cash conversion cycle to measure working capital management. The study found that the relationship among variables were strongly negative, suggesting that profit is negatively influenced by an increase in CCC. The study also found that as the debtor's collection period and inventory conversion period decreases, profitability increases.

[5] Conducted a study on the impact of Liquidity on Profitability of some selected companies in Nigeria and concluded that $75 \%$ of them indicated that current ratio has a significant positive correlation with profitability. The researcher believes that the reason for this positive relationship between current ratio and profitability is simply because idle funds, especially when borrowed, generates profits and less costs in the business. The two companies depicted a negative correlation between Acid test ratio and return on assets respectively. Thus, from the above results, $50 \%$ of the companies analyzed indicated a significant negative correlation between current ratio and profitability in this analysis.

[12], Investigated the impact of working capital management policies (aggressive and conservative policies) on the firms' profitability and value of listed companies in the Tehran Stock Exchange. The study used panel data and 17operationalized working capital management policy as conservative or aggressive. The results of the study shows that the application of a conservative investment policy and aggressive financing policy has a negative impact on a firm's profitability and value.

[2] On his study on his study on the relationship between working capital management policies and profitability for 


\section{International Journal of Science and Research (IJSR) \\ ISSN (Online): 2319-7064}

Index Copernicus Value (2015): 78.96 Impact Factor (2015): 6.391

companies quoted at the NSE found that the financial and investment sector has been able to achieve high scores on the various components of working capital and this has positive impact on profitability.

[9] Examined the effects of working capital management components on profitability of 30 firms listed at the NSE. The study used cash collection cycle to measure working capital. Mathuva (2009) applied the Pearson and Spearman's correlations, the pooled ordinary least squares and the fixed effects regression models in data analysis. The study found a highly significant negative relationship between profitability and the time it takes for firms to collect cash from their customers.The study also found a highly significant positive relationship between profitability and the period taken to convert inventories to sales and time it takes for firms to pay.

[12] Conducted a study to investigate the effects of working capital management practices on financial performance of Small-Scale Enterprises (SSEs) in Kisii South, Kenya. The study which adopted a cross-sectional survey research design, found that working capital management practices were low amongst SSEs as majority of them had not adopted formal working capital management routines. Similarly, their financial performance was on a low average. The study concluded that working capital management practices influence the financial performance of the SSEs. The study relied on primary qualitative data to measure working capital management practices

[8] Researched on the relationship between liquidity and profitability of oil companies in Kenya covering the period 2007 to 2010 . Secondary data was used in the analysis that was obtained from the firms' financial statements. A regression model was developed to determine the relationship between the dependent variable (profitability of the firms) and independent variables (liquidity position). The independent variable used in the model consisted of current ratio, quick ratio, cash conversion cycle, while leverage and the age of the firm were used as control variables. The study found that liquidity management is not a significant contributor alone to the firm's profitability and that there exists other variables that will influence ROA. However, it is important for a firm to understand the effect of each of the liquidity components on the firm's profitability and also undertake deliberate measures to optimize its liquidity level.

[13] Conducted a research on the effect of liquidity on financial performance of financial institutions listed at the NSE. The study depended on secondary data which was retrieved from the NSE's relevant financial statements. The study was conducted for the period 2011 to 2015.The researcher found out that the relationship between ROA and liquidity is negative implying that a decrease in liquidity will lead to a decrease in financial performance of financial companies listed at the NSE.

The empirical studies reveal contradicting results, mainly due to the studies being conducted under different economic conditions. However, the studies have tended to examine a wider area of liquidity, namely working capital. By expanding the area on liquidity, the research will study the effect of liquidity on the financial performance of all the firms listed at the NSE. Further, the data will extend over five years from 2010 to 2015 and this will allow the researcher to investigate the dynamic aspects with regard to the changing information impacts of liquidity. The international studies conducted in different countries are subject to different market conditions and stability, developed markets and emerging markets. It is thus inappropriate to apply the conclusions in Kenyan market condition which is a developing market. The relationship between liquidity and profitability is still not clear with some researchers indicating a positive relationship, while others indicating a negative or no relationship .It is with this hindsight that the researcher

\section{Problem Definition}

The recent financial crisis of 2007-2008 led to the closure of various funding sources leaving very many institutions short of cash required to cover their obligations as they fall due. Under 2007 crisis the financial sectors underwent a spillover where the foreign investors facing margin calls were forced to liquidate their equity positions in the developing countries. The condition was evidenced by the decline in the return on assets, increased leverage as well as declined returns on investments. Liquid assets such as cash and government securities generally have a relatively low return. Holding them impose an opportunity cost to the institutions. In the absence of regulation it is reasonable to expect companies to hold onto liquid assets only up to the extent at which they help maximize their profitability. The problem becomes how to select the optimum point at which an institution can maintain its liquid assets in order to optimize its return. The problem becomes severe as a number of institutions are engrossed with profit and shareholders' wealth maximization and as such they tend to neglect the importance of liquidity management as was the case during the financial crisis, this study will seek to establish the effect of liquidity on financial performance of the institutions listed in the NSE.

\section{Methodology}

This section discusses the research design to be used, the target population, sampling procedure and sample size, method of data collection and data analysis.

\section{Research Design}

The study adopted causal research design. According to [10], it is a research design aimed at analyzing how one variable produces a change in another variable or how one variable is responsible for changes in other variables.

\section{Target Population}

The target population of the study included the 66 firms listed at the NSE. The firms belong to different sectors of the economy. The target period for the study will be from the year 2010 to 2015 .

\section{Sampling Procedure}

The study adopted purposive sampling procedure as it enabled the researcher to select the sample size considered to be suitable of the study. The sample size will be 30 and

\section{Volume 6 Issue 7, July 2017 www.ijsr.net}




\section{International Journal of Science and Research (IJSR) \\ ISSN (Online): 2319-7064 \\ Index Copernicus Value (2015): 78.96 | Impact Factor (2015): 6.391}

the firms were selected based on their consistency to publish their financial statements from the period 2010 to 2015.

\section{Data Collection}

The study used secondary data, this is because all firms listed at the NSE are required to publish their audited financial statements and other Disclosures in a newspaper of nationwide circulation as well as display them on their websites. Of major scrutiny will be the statement of financial position (from which measures of current ratio, cash reserves and debt ratio will be obtained) and the statement of income (from which amounts of profit after tax for the 5 years will be obtained for the purpose of determining the Return on Assets). The study employed quantitative methodology in view to the nature of variables used for analysis. The researcher collected data on current assets, current liabilities, cash reserves, total assets and total liabilities. The data will be sourced from the NSE handbook.

\section{Data Analysis}

The data was edited, coded, classified, tabulated, cleansed and then transferred to the Statistical Package for the Social Science (SPSS) and results shown in terms of frequency distribution and percentages. The current ratio, quick ratio, debt ratio and ROA were calculated for period 2010 to 2015. The data will be analyzed using the multiple regression model.

\section{Regression Model}

Multiple regression model was used to establish the effect of each variable on financial performance. Regression is concerned with describing and evaluating the relationship between a given variable and one or more other variables.

The model is as shown below;

Where,

$\operatorname{ROA}_{i, t}=\beta_{0}+\beta_{1} \operatorname{Cr}_{i, t}+\beta_{2} \operatorname{Cshrsv}_{i, t}+\beta_{3} \operatorname{Dr}_{i, t}+\varepsilon$

$\beta_{0}=$ constant term

$\beta_{1}, \beta_{2}$ and $\beta_{3}$ are regression coefficients

$\mathrm{Cr}_{\mathrm{it}}, \mathrm{Cshrsv}_{\text {it }}$ and $\mathrm{Dr}_{\mathrm{it}}$ are independent variables

$\mathrm{ROA}_{\mathrm{i}, \mathrm{t}}=$ the dependent variable of firm i measured at time $\mathrm{t}$

$\mathrm{Cr}_{\mathrm{it}}=$ the current ratio of firm i measured at time $\mathrm{t}$

$\mathrm{Cshrsv}_{\mathrm{it}}=$ the amount of cash reserves of firm i measured at time $\mathrm{t}$

$\mathrm{Dr}_{\mathrm{it}}=$ the debt ratio of firm i measured at time $\mathrm{t}$

$\varepsilon=$ error term

\section{Results and Discussions}

This section presents the results and findings of the study.

\section{Descriptive Analysis}

Normality test is conducted to determine whether the data collected is normal and that the assumptions are met in your data for statistical tests.

Table 1: Descriptive Statistics

\begin{tabular}{|c|c|c|c|}
\hline Variables & Mean & Std. Deviation & $\mathrm{N}$ \\
\hline ROA & 0.60964 & 0.4585601 & 30 \\
\hline current ratio & 2.956677 & 2.328353 & 30 \\
\hline cash reserves & 1.424103 & 8.5725877 & 30 \\
\hline Debt ratio & 0.673258 & 0.3935672 & 30 \\
\hline
\end{tabular}

The mean is the average of all variables whereas standard deviation measures dispersion from the mean. Table 1 presents the descriptive statistics summary.

The mean for ROA was 0.0609640 for the selected 30 firms listed at the NSE. Current ratio had a mean of 2.956677 , cash reserves which was measured using the natural logarithm of the cash reserves had a mean of 1.424103 while the debt ratio for the 30 firms had a mean of 0.673258 . Standard deviation measures dispersion from the mean and describes data location with respect to the mean. The ROA had a standard deviation of 0.458560 , the current ratio 2.328350 , the cash reserves having a deviation of 8.5725877 and the debt ratio a deviation of 0.3935672 for the 30 firms.

\section{Correlation Analysis}

Correlation analysis tests for the relationship between dependent variable and independent variable. Pearson Product Moment correlation efficient technique was used to establish the strength of relationship between the independent and dependent variables of the 30 selected firms.

\section{Correlation between Current ratio and ROA}

Table 2

\begin{tabular}{|c|c|c|c|}
\hline \multicolumn{4}{|c|}{ Correlation } \\
\hline Variable & & current ratio & ROA \\
\hline \multirow{4}{*}{} & Pearson Correlation & 1 & 0.73 \\
\cline { 2 - 4 } & Sig. (2-tailed) & & 0 \\
\cline { 2 - 4 } & N & 30 & 30 \\
\hline \multirow{3}{*}{ ROA } & Pearson Correlation & 0.73 & 1 \\
\cline { 2 - 4 } & Sig. (2-tailed) & 0 & \\
\cline { 2 - 4 } & $\mathrm{N}$ & 30 & 30 \\
\hline
\end{tabular}

The results from Table 2 above shows that the relationship between current ratio and ROA is fairly strong, positive and statistically significant. (Current ratio $=0.73, \mathrm{P}$ value $=0.000<0.05)$. This implies that current ratio and ROA are perfectly positively correlated.

\section{Correlation between Cash Reserves and ROA}

Table 3: Correlation between cash reserves and ROA

\begin{tabular}{|c|c|c|c|}
\hline Variable & & ROA & cash reserves \\
\hline \multirow{4}{*}{$\begin{array}{c}\text { cash } \\
\text { reserves }\end{array}$} & Pearson Correlation & 1 & 0.707 \\
\cline { 2 - 4 } & Sig. (2-tailed) & & 0 \\
\cline { 2 - 4 } & N & 30 & 30 \\
\cline { 2 - 4 } & Searson Correlation & 0.707 & 1 \\
\cline { 2 - 4 } & N & 30 & 30 \\
\hline \multicolumn{4}{|c|}{ Correlation is significant at the 0.01 level (2-tailed). } \\
\hline
\end{tabular}

The table above shows that the relationship between cash reserves and ROA is also fairly strong, positive and statistically significant. Cash reserves $=0.707$ and a $\mathrm{P}$ value of $0.000<0.05$. 


\section{International Journal of Science and Research (IJSR)}

ISSN (Online): 2319-7064

Index Copernicus Value (2015): 78.96 | Impact Factor (2015): 6.391

Correlation between Debt Ratio and R.O.A

Table 4

\begin{tabular}{|c|c|c|c|}
\hline \multicolumn{4}{|c|}{ Correlation } \\
\hline Variable & \multicolumn{2}{|c|}{ ROA } & Debt ratio \\
\hline \multirow{3}{*}{ ROA } & Pearson Correlation & 1 & 0.242 \\
\cline { 2 - 4 } & Sig. (2-tailed) & & 0.198 \\
\cline { 2 - 4 } & $\mathrm{N}$ & 30 & 30 \\
\hline \multirow{3}{*}{ Debt ratio } & Pearson Correlation & 0.242 & 1 \\
\cline { 2 - 4 } & Sig. (2-tailed) & 0.198 & \\
\cline { 2 - 4 } & $\mathrm{N}$ & 30 & 30 \\
\hline
\end{tabular}

Results from table 4 shows that the relationship between debt ratio and ROA is weak, fairly positive and statistically insignificant. Debt ratio $=0.242, \mathrm{P}$ value $=0.198>0.05$. This implies debt ratio and ROA are weakly positively correlated.

\section{Test for Significance of the Regression coefficients}

The study was based on the assumption that the independent variables have no significant effect on the dependent variables. Coefficients of the independent variables were tested using the t-test to determine whether they are significant at $95 \%$ level of confidence.

Table 5: Coefficients

\begin{tabular}{|c|c|c|c|c|c|c|}
\hline & \multirow{2}{*}{ B } & \multirow{2}{*}{ Std. Error } & \multirow{2}{*}{ Unstandardized Coefficients } & \multirow{2}{*}{ Sig. } & Collinearity Statistics & \multirow[b]{2}{*}{ VIF } \\
\hline & & & & & \begin{tabular}{|l|} 
Tolerance \\
\end{tabular} & \\
\hline (Constant) & -0.104 & 0.121 & & 0.399 & & \\
\hline Current ratio & 0.098 & 0.024 & 0.496 & 0 & 0.702 & 1.425 \\
\hline Cash reserves & 0.026 & 0.006 & 0.492 & 0 & 0.795 & 1.258 \\
\hline Debt ratio & 0.074 & 0.129 & 0.064 & 0.571 & 0.861 & 1.161 \\
\hline
\end{tabular}

Standardized coefficients are the estimates resulting from an analysis performed on variables that have been standardized so that they have variances of 1 . Unstandardized variable shows the average change in dependent variable as a result of a unit change in the independent variable, statistically controlling the other independent variable. Thus for the purpose of this study, unstandardized coefficients were used.

\section{Effect of Current ratio on Profitability}

The hypothesis that Current ratio has no significant effect on profitability of the firms listed at the NSE was tested using the t-test to determine its rejection or acceptance. ROA was used to measure profitability and the results indicates a positive relationship with the current ratio. From the above table it can be concluded that a unit increase in current ratio result in 0.098 increase in ROA. Current ratio has a $\mathrm{P}$ value of 0.000 which is less than 0.05 hence statistically significant at $5 \%$. This results into the rejection of the null hypothesis that states that current ratio has no significant effect on the financial performance. This is in line with the Nyamao et al (2012) whose study investigated the effects of working capital management practices on financial performance of Small Scale enterprises and concluded that an increase in working capital management results into an increase in financial performance.

\section{Effect of Cash Reserves on Profitability}

The hypothesis stating that cash reserves have no significant effect on profitability was tested using t-test. The cash reserves was measured using the natural logarithm of the total reserves. From the above data it can be concluded that a unit increase in cash reserves results to a 0.026 increase in ROA. The cash reserves has a $\mathrm{p}$ value of 0.000 which is less than 0.05 implying that it is statistically significant at $5 \%$ level of significance. This leads to the rejection of the null hypothesis since an increase in cash reserves results into an increase in ROA.

\section{Effect of Debt Ratio on Profitability}

The hypothesis that debt ratio has no significant effect on financial performance was tested using the t-test. The table above shows that a unit increase in debt ratio results to a 0.074 increase in ROA. The debt ratio was measured as total liabilities divided by total assets. The debt ratio has a $\mathrm{p}$ value of 0.571 which is more than 0.005 implying that it is insignificant at 5\% level of significance. This leads to the acceptance of the null hypothesis which states that the debt ratio has no significant effect on ROA.

\section{Model Specification}

The model was used to establish the cause-effect relationship between the dependent and independent variable.

Table 6

\begin{tabular}{|c|c|c|c|c|c|}
\hline \multicolumn{7}{|c|}{ Model Summary } \\
\hline Model & R & R Square & $\begin{array}{c}\text { Adjusted } \\
\text { R Square }\end{array}$ & $\begin{array}{c}\text { Std. Error of the } \\
\text { Estimate }\end{array}$ & $\begin{array}{c}\text { Durbin- } \\
\text { Watson }\end{array}$ \\
\cline { 4 - 5 } & & & 0.693 & 0.2540967 & 1.408 \\
\hline 1 & 0.851 & 0.725 & 0.69 & \\
\hline
\end{tabular}

Table 6 is the model summary with the value of R square as 0.721 implying that about $72.1 \%$ of variation can be explained by the independent variables and $28 \%$ of the variation may be due to other factors beyond the control of the researcher. The regression results indicates that the independent variables; current ratio and cash reserves are significant in affecting the ROA of the firms listed at the NSE. Adjusted $\mathrm{R}^{2}$ is the coefficient determination which explains disparities in the dependent variable due to changes in the independent variable. From the table above, findings of the adjusted $\mathrm{R}$ square was 0.701 indicating a variation of $70.1 \%$ of the listed firms at the NSE is due to the changes in the independent variable.

Table 7: ANOVA

\begin{tabular}{|c|c|c|c|c|c|c|}
\hline \multicolumn{2}{|c|}{ Model } & Sum of Squares & Df & Mean Square & F & Sig. \\
\hline \multirow{3}{*}{1} & Regression & 4.398 & 2 & 2.199 & 34.926 & 0 \\
\cline { 2 - 8 } & Residual & 1.7 & 27 & 0.063 & & \\
\cline { 2 - 8 } & Total & 6.098 & 29 & & & \\
\hline
\end{tabular}




\section{International Journal of Science and Research (IJSR) \\ ISSN (Online): 2319-7064}

Index Copernicus Value (2015): 78.96 | Impact Factor (2015): 6.391

Table 7 represents the ANOVA table which was used to test whether the predictors have significant effect on the dependent variable. If one predictor is dropped the dependent variable will be significantly affected as it will generate a value more than $0.05 \mathrm{p}$ value. The $\mathrm{F}$ value from the table is significant at $5 \%$ level $(\mathrm{F}=34.926, \mathrm{P}<0.05)$ implying that the model is applicable.

\section{Regression Equation}

The independent and dependent variables are related using the multiple linear regression equation shown below; $\mathrm{ROA}_{\mathrm{i}, \mathrm{t}}=-0.104+0.098 \mathrm{Cr}_{\mathrm{i}, \mathrm{t}}+0.026 \mathrm{Cshrsv}_{\mathrm{i}, \mathrm{t}}+0.074 \mathrm{Dr}_{\mathrm{i}, \mathrm{t}}$

The above regression equation reveals that a unit increase in the current ratio would lead to an increase in the profitability of the firms by a factor of 0.098 , a unit change in the cash reserves of the firms would lead to an increase in their profitability by a factor of 0.026 . Debt ratio was statistically insignificant as it had a $\mathrm{P}$ value of 0.571 which is above the 0.05 level of significance. The debt ratio has a coefficient of 0.074 , this means that a unit increase in the debt ratio results to an increase in the ROA by 0.074 units. The coefficients of the current ratio and cash reserves are 0.098 and 0.026 respectively as depicted in table 7 . The coefficients of the independent variables (current ratio and cash reserves) were tested using the t-test to determine their significance levels. The $\mathrm{P}$ values calculated for the current ratio and cash reserves were less than 0.05 thus significant at $5 \%$ level of significance. The expected value of the error term was equal to zero hence the error term was also not included in the regression equation.

\section{Conclusion}

Liquidity plays a major role in influencing the profitability of the firms listed at the NSE. It must therefore be given an emphasis in the financial department of the firms by ensuring that the firms have adequate amounts required for the purpose of meeting their obligations, as and when they fall due so at to maximize their ROA. The study considered the three measures of liquidity which are; current ratio, cash reserves, debt ratio and concluded that liquidity has an effect on the financial performance of firms listed at the NSE, especially the current ratio and cash reserves which were found to be statistically significant at 5\% significance level as they both had a significance level of $\mathrm{p}=0.000$. This led to the rejection of the null hypothesis which stated that both the current ratio and the cash reserves have no significant effect on financial performance of firms listed at the NSE. The debt ratio was found to have a $\mathrm{P}$ value of 0.571 which is greater than 0.05 level of significance. The null hypothesis that stated debt ratio has no significant effect on financial performance was hence accepted because the debt ratio was statistically insignificant at $5 \%$ level of significance. The hypotheses of the current ratio and cash reserves were found to be in line with the Keynesian Liquidity theory which stipulates that firms must hold certain percentage of their total finance in cash so as to be able to meet their precautionary, transaction and speculative needs effectively.

\section{References}

[1] Alshatti A.S. (2015), Effect of liquidity management on profitability of Jordanian. Commercial banks. InternationalJournalofBusinessandManagement. 10(1), 62-71

[2] Apuoyo, B.O. (2010). The relationship between working capital management policies and Profitability for companies quoted at the NSE. UnpublishedMBAproject, University of Nairobi.

[3] Basel Committee on Banking Supervision, (2013). The liquidity overage ratio and liquidity risk monitoring tools. Bank of International settlement.

[4] Dong, H.P. \& Su, J. (2010). The relationship between working capital management and Profitability. A Vietnam case. International Research Journal of FinanceandEconomics, 49, 59-67

[5] Ehiedu, V.C. (2014). The impact of liquidity on profitability of some selected companies. The Financial Statement Analysis (FSA) Approach. Research Journal of Finance and Accounting. The International Institute of Scienceand Technology and Education(IISTE).5(5), 72-80.

[6] Eljelly,A.M.A.(2004) "Liquidity-Profitability tradeoff. An empirical investigation in an emerging market," InternationalJournal of Commerce andManagement, 14(2), 48

[7] Maaka,Z.(2013). Relationship between the liquidity risk and financial performance of commercial banks in Kenya. UnpublishedMBAproject, University of Nairobi

[8] Maina,H.(2011). Relationship between the liquidity and profitability of oil companies in Kenya. Unpublished MBA project, University of Nairobi.

[9] Mathuva, M.D. (2009). The influence of working capital management components on corporate profitability: A survey of Kenyan listed firms, Journal of Financial Management, 15(2), 24-35

[10] Mugenda,M \& Mugenda,G. (1999).Research methods. Quantitative and Qualitative Approaches. Nairobi, Kenya.

[11] Njoroge,I.M.(2015) Effect of liquidity on financial performance of construction and allied and companies listed at the NSE. UnpublishedMBAproject, Nairobi, University.

[12] Nyamao, N.R., Ojera, P., Lumumba, M, Odondo, A.J and Otieno, S. (2012). Effect of working capital management practices on Financial Performance: A study of small scale enterprises in Kisii South District, Kenya. AfricanJournalofBusinessManagement, 6(18), 5807-5817.

[13] Omesa,J.(2015). Effect of liquidity on the financial Performance of financial institutions listed at the NSE. UnpublishedMBAproject, university of Nairobi.

[14] Pandey, I.M. (2008). Financial Management.Vikas Publishing House PVT Limited: New Dheli.

[15] Sekaran, U\&Bougle, R. (2010). Research methods for business. A skill Building Approach (5thEd).United States of America. 